\title{
Buformin Concentrations in a Case of Fatal Lactic Acidosis
}

\author{
L. F. Verdonck ${ }^{1}$, B. Sangster ${ }^{2}$, A. N. P. van Heijst ${ }^{2}$, G. de Groot ${ }^{3}$, and R. A. A. Maes ${ }^{3}$ \\ Departments of ${ }^{1}$ Internal Medicine and ${ }^{2}$ Reanimation and Clinical Toxicology, University Hospital, Utrecht, \\ and National Poison Control Centre, National Institute of Public Health, Bilthoven, and ${ }^{3}$ Centre for Human Toxicology, State University, \\ Utrecht, Netherlands
}

Summary. A fatal case of lactic acidosis in a 84 year old diabetic woman taking buformin is reported. Buformin concentrations in serum, other body fluids and tissues were measured by gas chromatography. Serum buformin concentration at admission was $5.5 \mathrm{mg} / 1$. Postmortem concentrations were: in serum $3.2 \mathrm{mg} / \mathrm{l}$; in lung $2.8 \mathrm{mg} / \mathrm{kg}$ wet weight; in heart $3.0 \mathrm{mg} / \mathrm{kg}$; in pericardial fluid $3.5 \mathrm{mg} / \mathrm{l}$; in liver $5.2 \mathrm{mg} / \mathrm{kg}$; in bile $6.3 \mathrm{mg} / \mathrm{l}$; and in kidney $98 \mathrm{mg} / \mathrm{kg}$.

Key words: Lactic acidosis, plasma buformin concentration, tissue buformin concentration, biguanides.

Biguanides may cause lactic acidosis. Clinical observations and experimental research have given a better understanding of the circumstances under which lactic acidosis may develop and of the pathophysiological mechanisms that form its basis. However, few data are available on the concentrations of these drugs in plasma, other body fluids and tissues both during normal therapy [1] and when lactic acidosis has developed $[1,2,3,4]$.

A case of fatal lactic acidosis during treatment with buformin, in which concentrations of the drug were measured, is described.

\section{Case Report}

An 84 year old woman was admitted to the University Hospital, Utrecht because of subcoma, haematemesis and hypotension. She was a known diabetic with hypertension and was treated with diet, tolbutamide ( $500 \mathrm{mg} 3$ times a day), buformin (100 mg 2 times a day) and $\alpha$-methyldopa ( $250 \mathrm{mg} 2$ times a day). Buformin was commenced $2 \frac{1}{2}$ years before admission. Serum creatinine had always been within normal limits.

At admission the patient was unconscious with hyperventilation. The pulse rate was $80 / \mathrm{min}$, irregular and inequal. Blood pressure was $90 / 60 \mathrm{~mm} \mathrm{Hg}$ and temperature $35.5^{\circ} \mathrm{C}$. Skin turgor was normal. Laboratory data included: haemoglobin $8.0 \mathrm{mmol} / 1$ $(12.8 \mathrm{~g} / \mathrm{dl})$, haematocrit 0.42 , blood glucose $7.2 \mathrm{mmol} / \mathrm{l}$, urea $14.9 \mathrm{mmol} / \mathrm{l}$, creatinine $285 \mathrm{Umol} / 1, \mathrm{Na}^{+} 138 \mathrm{mmol} / 1, \mathrm{~K}^{+}$ $4.8 \mathrm{mmol} / 1, \quad \mathrm{Cl}^{-} 91 \mathrm{mmol} / 1$, bicarbonate $5.5 \mathrm{mmol} / \mathrm{l}, \mathrm{Ca}^{++}$ $2.60 \mathrm{mmol} / 1$, lactate $29.8 \mathrm{mmol} / 1$, aniongap $41.5 \mathrm{mmol} / 1$. Arterial blood: $\mathrm{P}_{\mathrm{O}_{2}} 132 \mathrm{~mm} \mathrm{Hg}, \mathrm{P}_{\mathrm{CO}_{2}} 10.5 \mathrm{~mm} \mathrm{Hg}, \mathrm{pH}$ 6.83. Liver-function tests and plasma proteins were normal. Chest $\mathrm{X}$-ray was normal. The ECG showed artrial tibrillation and slight nonspecific STdepression in all leads. A stomach tube was inserted and old blood found.

\section{Subsequent Progress}

Therapy with IV bicarbonate, up to $420 \mathrm{mmol}$, was started and 20 $\mathrm{U}$ insulin (Actrapid) was given. Fluid replacement with ' $500 \mathrm{ml}$ plasma and $1500 \mathrm{ml}$ of an isotonic saline-glucose solution was added to the bicarbonate therapy. Methylprednisolone $1000 \mathrm{mg}$ and digoxin were administered intravenously. The condition of the patient deteriorated and she died $6 \mathrm{~h}$ after admission.

\section{Postmortem Results}

A postmortem was performed.(J. K. Vețte, Institute for Pathology, State University, Utrecht) and showed diffuse hyalinisation of the islets of Langerhans, slight diffuse atherosclerosis of the coronary arteries, and intracapillary diabetic glomerulosclerosis and atherosclerosis in the kidneys.

\section{Buformin Concentrations}

Buformin concentrations were determined by gas chromatography [5]. At admission the serum buformin concentration was $5.5 \mathrm{mg} / \mathrm{l}$. Postmortem concentrations of the drug were: in serum $3.2 \mathrm{mg} / 1$; in lung $2.8 \mathrm{mg} / \mathrm{kg}$ wet weight; in heart $3.0 \mathrm{mg} / \mathrm{kg}$; in pericardial fluid $3.5 \mathrm{mg} / \mathrm{l}$; in liver $5.2 \mathrm{mg} / \mathrm{kg}$; in bile $6.3 \mathrm{mg} / \mathrm{l}$; in kidney $98 \mathrm{mg} / \mathrm{kg}$.

\section{Discussion}

The causes that initiated the lactic acidosis in this patient cannot be established with certainty. The haemoglobin concentration and the absence of clinical and postmortem signs of a large haemorrhage make it unlikely that marked hypovolaemia was important.

For $2 \frac{1}{2}$ years her diabetes mellitus had been adequately controlled by an unchanged therapeutical regimen. However, renal function was disturbed at admission. It is possible that some time before the occurrence of lactic acidosis a developing diabetic nephropathy and the existing hypertension had led to a decrease of renal function. This could have caused 
accumulation of buformin and subsequently lactic acidosis [6]. The acidosis may have caused cardiac failure [7, 8], a further decrease of renal function [9] and a further increase of the severity of the lactic acidosis.

The ability of biguanides to lower blood glucose concentration is explained by several mechanisms [ 2 , $6,10,11]$. The effects of biguanides on lactic acid production have been reviewed $[4,6]$. Briefly, biguanides are probably bound to the mitochondrial membrane, changing its electrochemical properties, and thereby interfering with the entrance of NADH into the mitochondrion, shifting the reaction pyruvate $+\mathrm{NADH} \leftrightarrows$ lactate $+\mathrm{NAD}^{+}$to the right. This enhances the production of lactate. Thus increase of the biguanide concentration results in lactic acidosis [12].

Buformin is completely absorbed from the intestinal tract. The therapeutic plasma concentration is about $0.5 \mathrm{mg} / \mathrm{l}$. Plasma half-life is about $2 \mathrm{~h}$. Buformin is almost completely excreted by the kidneys as the unchanged drug by both glomerular filtration and tubular secretion. Renal clearance is about $450 \mathrm{ml} /$ min $[1,11,13]$. After oral as well as IV administration of labelled buformin in human diabetics with normal renal function the buformin concentrations in the intestinal mucosa and the liver were many times. higher than in plasma; especially after oral administration. The liver concentrations were $10-20 \mathrm{mg} / \mathrm{kg}$. Similar differences between plasma and liver tissue concentrations were found in animal studies [14].

In patients with lactic acidosis during buformin therapy plasma concentrations up to $3.0 \mathrm{mg} / 1$ have been measured $[2,3,11]$. No data are available on buformin concentrations in other body fluids and tissues during lactic acidosis.

The buformin concentration in plasma of $5.5 \mathrm{mg} / \mathrm{l}$ in the patient described is high. The lower concentration of $3.2 \mathrm{mg} / \mathrm{l}$ obtained at the postmortem may be explained by dilution as a result of treatment. Redistribution after death may also be involved. The concentrations of buformin in the heart, the lungs and the liver were of the same magnitude as in the blood. The concentration in the kidneys was 20 times that in other organs, reflecting the route of elimination. The severe lactic acidosis and state of shock presumably contributed to the lack of a significant difference between the concentrations in blood and liver. Again, however, redistribution after death may also have occurred.

The question arises as to why a lactic acidosis suddenly develops without a complicating illness in a patient using buformin for $2^{1 / 2}$ years. Progression of diabetic microangiopathy results in a gradual loss of nephrons and thereby a decreased glomerular filtration rate. Consequently, the buformin concentrations in the blood and the peritubular fluid would increase.
This may result in an increase of tubular secretion until the maximal tubular secretion rate of buformin is reached. Until then the loss of nephrons causes only a small increase in plasma half-life. A further loss cannot result in a further increase in tubular secretion. Only the amount filtered in the remaining nephrons rises in proportion to the concentration in the plasma. Consequently a further loss of nephrons will cause a faster rise in plasma half-life and a dramatic increase in plasma and tissue concentrations. This may explain why after many years lactic acidosis may develop suddenly.

\section{References}

1. Lintz W, Berger W, Aenishaenslin W, Kutova V, Baerlocher Ch, Kapp JP, Beckmann R (1974) Butylbiguanide concentration in plasma, liver, and intestine after intravenous and oral administration to man. Eur J Clin Pharmacol 7: 433-448

2. Berger W, Mehnert-Aner S, Mülly K, Heierli Ch, Ritz R (1976) 10 Fälle von Lactatazidose unter Biguanidtherapie (Buformin und Phenformin). Schweiz Med Wochenschr 106: $1830-1834$

3. Althoff PH, Fassbinder W, Neubauer M, Koch KM, Schöffling K (1978) Hämodialyse bei der Behandlung der biguanidinduzierten Lactacidose. Disch Med Wochenschr 103: 61-68

4. Irsigler K, Kritz H, Regal H, Foltin E (1978) Risiko zur Laktazidose? Wien Klin Wochenschr 90: 332-337

5. Groot $G$ de, Maes RAA, Sangster B, Heijst ANP van, Verdonck LF (1980) A specific method for the analysis of bufor$\mathrm{min}$ in pre- and postmortem human material. Proceedings of the European Meeting of the International Association of Forensic Toxicologists, Glasgow, August 1979. Croom Helm, London, P 165-172

6. Alberti KGMM, Nattrass M (1977) Lactic acidosis: Lancet II: 25-29

7. Ng ML, Levy MN, Zieske HA (1967) Effects of changes of $\mathrm{pH}$ and carbon dioxide tension on left ventricular performance. Am J. Physiol 213: 115-120

8. Wildenthal K, Mierzwiak DS, Myers RW, Mitchell JH (1968) Effects of acute lactic acidosis on left ventricular performance. Am J Physiol 214: 1352-1359

9. Zähringer J, Cyran J, Lüderitz B (1978) Laktazidose bei Biguanidtherapie: Diagnostik und Therapie. Schweiz Med Wochenschr 108: 1838-1846

10. Bottermann P, Schweigart U, Ermler R (1976) Untersuchungen zum Wirkungsmechanismus von Buformin mit Hilfe tritiierter Glucose bei stoffwechselgesunden Personen. Med Klin 71: 1423-1428

11. Deppermann D, Heidland A, Ritz E, Hört W (1978) LactatAzidose. Eine mögliche Komplikation der Buformin-Therapie. Klin Wochenschr 56: 843-853

12. Luft D, Schmülling RM, Eggstein M (1978) Lactic acidosts in biguanide-treated diabetics. Diabetologia 14: 75-87

13. Beckmann R, Lintz W, Schmidt-Böthelt E (1971) Evaluation of a sustained release from of the oral antidiabetic butylbiguanide (Silubin ${ }^{\text {}}$-Retard). Eur J Clin Pharmacol 3: 221-228

14. Losert W, Kolb K-H, Bitterling G (1972) Verteilung von 1Buryl-biguanid. ${ }^{14} \mathrm{C}$ im Organismus von Ratten und Meerschweinen. Arzneim Forsch 22: 937-946

Received: October 3, 1979,

and in revised form: September 5, 1980

Dr. B. Sangster, Internist

Academisch Ziekenhuis Utrecht

Postbus 16250

3500 CG Utrecht, Netherlands 